Rafal S. Jurecki

\title{
ANALYSIS OF ROAD SAFETY IN POLAND AFTER ACCESSION TO THE EUROPEAN UNION
}

The article presents an assessment of the state of safety on Polish roads in the period 2004-2018 in terms of changes that occurred after Poland's accession to the EU. The number of vehicles in the period in question was analyzed and the annual growth of the number of vehicles of the main types was assessed. Analysis of changes in the length of the most important road types was carried out. The number of accidents and fatalities was analyzed and the changes in this area were assessed. The statistical decrease in the number of accidents and fatalities, as well as a very strong correlation between them, were confirmed. It was indicated in which groups of accidents the fatality risk is the highest. The paper presents a summary of the types of roads on which traffic accidents and fatal traffic accidents occurred. Shares of these roads were determined, indicating that the most dangerous roads in Poland are the two-way, two-lane roads.

Keywords: road safety, accident, accident statistics

\section{Introduction}

The use of cars has become commonplace in everyday life. Unfortunately, the road traffic is a source of traffic events hazardous to the health and life of road users. Every year, there are tens of thousands of accidents in Poland, with several thousand fatalities. Tens of thousands of people are injured in these accidents, which is of no less importance. Traffic accidents have significant social and economic consequences [1-2]. In 2004, the unit cost of a fatality in Poland, estimated according to the PANDORA 2014 method, was approximately PLN 2.05 million and that of severely injured person was PLN 2.32 million. In Poland, the costs of accidents in the year 2004 amounted to about PLN 30 billion [2].

Due to the significance of the traffic accidents problem, a number of publications [3-5] have undertaken analysis of the state of safety on roads of a multitude countries, including Poland [6-8]. This is despite the fact that the roads in the EU are considered to be among the safest in the world. Among those involved in the matters of the road safety, one question is still being raised: what solutions should be implemented to reduce accident rates and their negative consequences? In order to consider these issues, an in-depth analysis of the causes and consequences of traffic accidents is necessary, taking into account various factors [9]. Factors that may determine the possibility of traffic accidents include: the state of road infrastructure in a given country [10], technical factors [11], cultural factors, e.g. inclination to respect the provisions of the Road Code, alcohol consumption, psychological factors [12], road factors [13-14], etc. Problems related to road safety were analyzed in a number of publications [15-17].

In 2004, Poland was included into the European Union. Since then, significant changes have taken place in many aspects of life in Poland. The possibility of free movement in Europe within the Schengen Area, liberalization of many regulations caused changes in the structure of exploited vehicles caused by a large influx of used vehicles. At the same time, along with numerous investments in infrastructure, significant changes have taken place in the broadly understood road surroundings.

The article analyzes selected factors that impact the safety on Polish roads.

\section{Vehicles in Poland}

The number of vehicles registered in Poland in the analyzed period has significantly changed. In nearly 15 years, it has increased from approximately 16.7 million to nearly 30 million. If we take the 2004 (as 100\%) as a baseline value, the recorded increase in this respect reached $77 \%$ [18].

At the same time, the number of passenger cars has increased from nearly 12 million to over 22.5. In turn, this translates into an increase of nearly $90 \%$. The number of trucks (44\%) and motorcycles (71\%) also increased. A summary of the numbers of motor vehicles and passenger cars is presented in Figure 1. When analyzing the number of registered vehicles and population [19], it can be observed that the number of passenger cars per 1000 residents in

\section{Rafal S. Jurecki}

Department of Automotive Engineering and Transport, Faculty of Mechatronics and Automotive Engineering, Kielce University of Technology, Poland

E-mail of corresponding author: rjurecki@tu.kielce.pl 


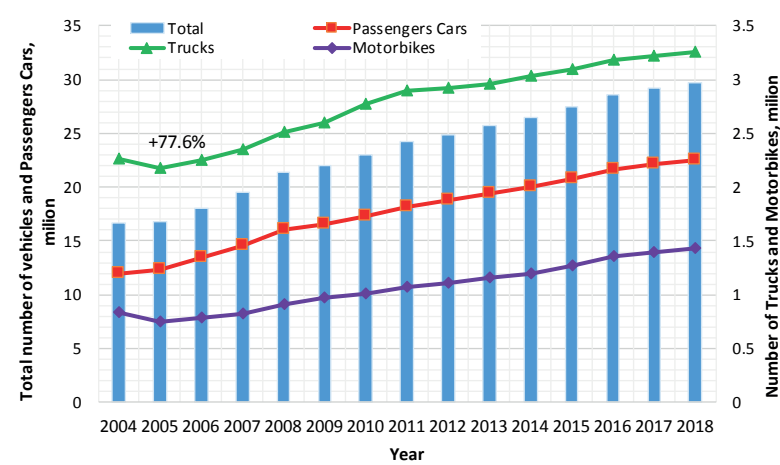

Figure 1 Numbers of vehicles by type in Poland between 2004 and 2018

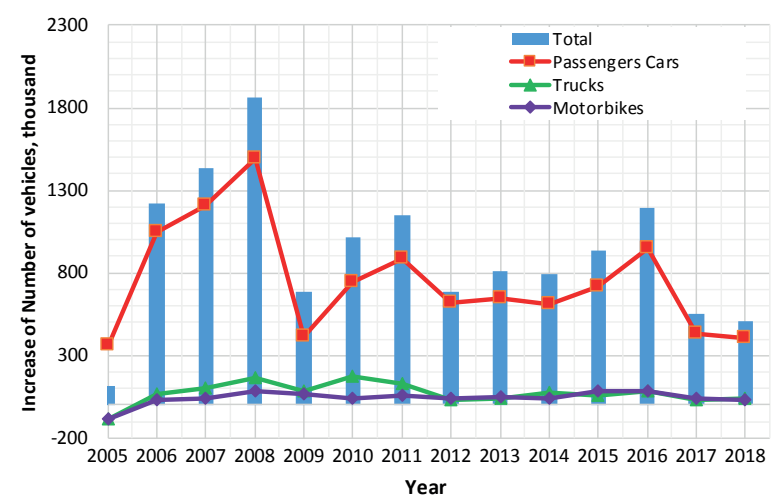

Figure 2 Change in the numbers vehicles by type

Poland increased form 314 in 2004, and to 586 cars in 2018. In this respect, Poland is currently one of the leading European countries.

After the borders were opened and procedures such as customs formalities were simplified, the annual increases in the number of cars were significant, as shown in Figure 2.

One of the main factors influencing the increase in the total number of vehicles was the change in the number of passenger cars. In the record-breaking year of 2008, the growth of all registered vehicles reached 1.85 million vehicles, 1.5 million of which were passenger cars. If the relative changes in the number of vehicles (Figure 3) in particular groups of vehicles are analyzed, it is clear that the only decrease was recorded in 2005 (compared to 2004) with regard to the number of trucks and motorcycles.

In 2008, the highest relative increase in the number of passenger cars, motorcycles and trucks was recorded $-7-10 \%[18]$.

\section{Changes to roads in Poland}

There are over 420 thousand public roads in Poland [8, 20]. In recent years, especially after Poland's accession to the $\mathrm{EU}$, the road network has undergone certain changes. The length of public roads has increased relatively little,

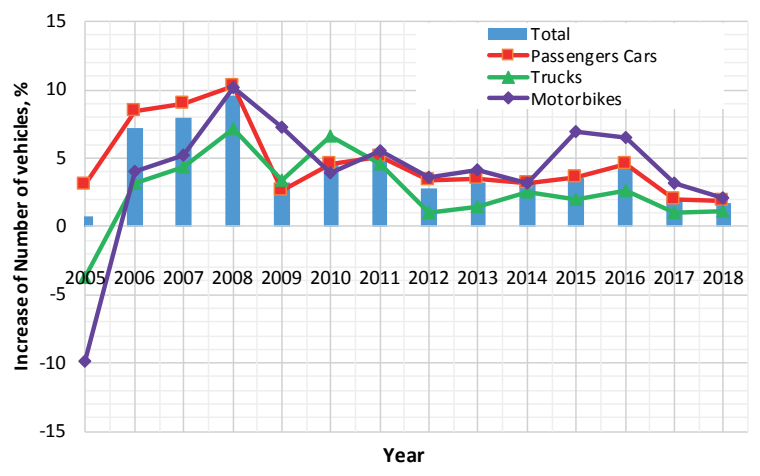

Figure 3 Relative change in numbers of vehicles

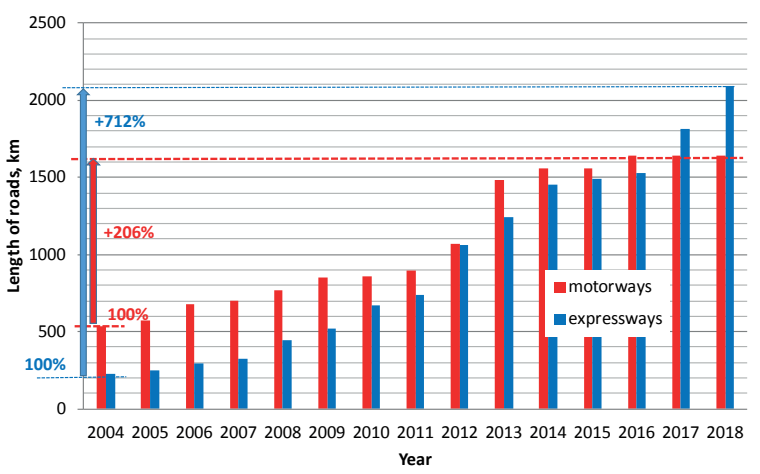

Figure 4 Change in the length of the most important roads in Poland in the years 2004-2018

by slightly more than $10 \%$. However, the changes are particularly visible in the case of national roads [21], as well as expressways and motorways [22].

The change in the length of the most important roads in Poland is presented in Figure 4 [22]. At the end of 2018, the total length of expressways and motorways in Poland amounted to $2092 \mathrm{~km}$ and $1638 \mathrm{~km}$, respectively. In total, these roads in relation to all the public roads in Poland constitute only just over $0.8 \%$ of all roads.

In Europe, Spain has the most developed motorway network, having more than 17 thousand $\mathrm{km}$ of motorways on an area of 500 thousand $\mathrm{km}^{2}$ [6]. In Germany (total area of 357 thousand $\mathrm{km}^{2}$ ) there are 15.3 thousand $\mathrm{km}$ of such roads, while in France ( 551 thousand $\mathrm{km}^{2}$ ) -just over 11.6 thousand $\mathrm{km}$ of such roads [18, 23]. The length of such roads per total area of a country is an indicator that determines the degree of development of the road network and the density of the best roads. In Poland, it is only 0.005 $\mathrm{km} / 1 \mathrm{~km}^{2}$, while in Belgium it is $0.058 \mathrm{~km} / 1 \mathrm{~km}^{2}$, Holland $0.074 \mathrm{~km} / 1 \mathrm{~km}^{2}$, Spain $0.0344 \mathrm{~km} / 1 \mathrm{~km}^{2}$.

Apart from expressways and motorways [22], Poland has nearly 20 thousand $\mathrm{km}$ of national roads [24]. All of them include the most important road routes managed by the Polish General Directorate for National Roads and Motorways (GDDKiA). In Poland, these constitute nearly $5 \%$ of all available roads. 


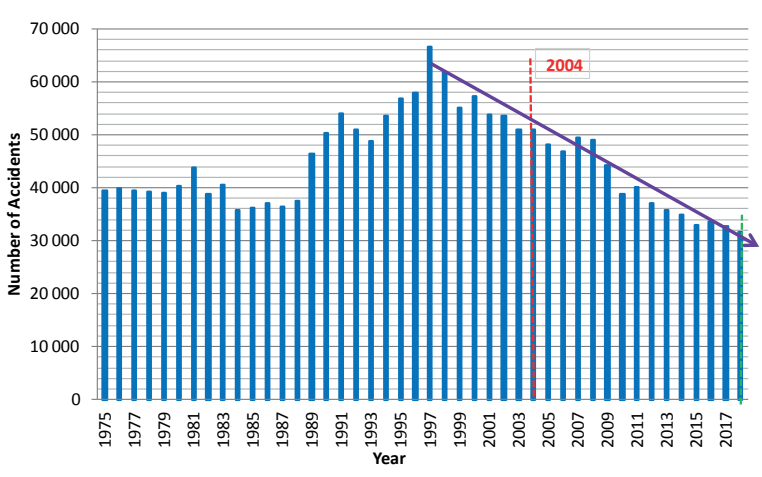

Figure 5 Number of traffic accidents in Poland

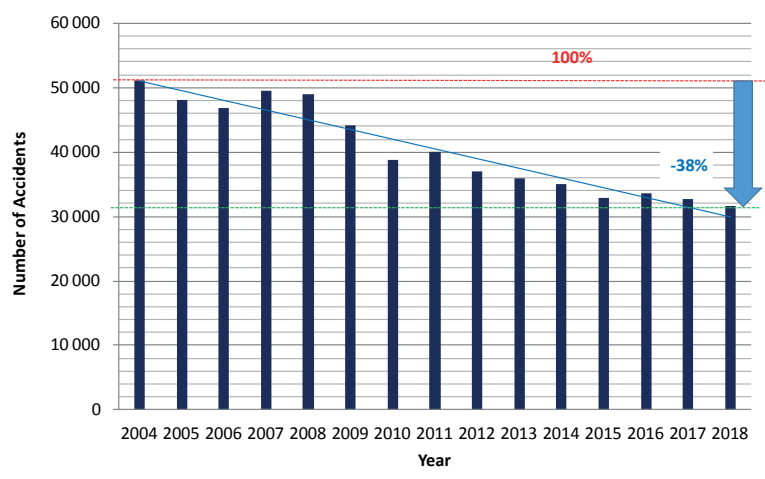

Figure 6 Decrease of number of traffic accidents in Poland in 2004-2018

If 2004 is assumed as the baseline for the state of roads, in nearly fifteen years the length of motorways has increased by more than $206 \%$, while the length of expressways has increased by $712 \%$.

\section{Traffic accidents, their causes and consequences}

The road traffic generates the danger of collisions and accidents. Unfortunately, these incidents are still an integral part of the road traffic. Despite many actions taken both in Poland [25-27] and by EU authorities [28-30], the still unattainable and still time-shifted goal is to halve the number of deaths. Such an ambitious goal was set earlier for the year 2020 (in relation to 2010) [28, 30].

In Poland, in the analyzed years, considering the significant density of traffic, the statistically assessed road safety improved, although it was subject to significant fluctuations [7, 16, 31]. To make the state of safety in Poland easier to assess, Figure 5 shows the number of accidents in the last 40 years.

From such a perspective, it is clear that the culmination point of the number of accidents on Polish roads (which occurred many years before Poland's accession to the EU) was in 1997. A record number of over 66 thousand accidents was recorded in Poland in that year. In order to indicate the importance of the problem, it is worth mentioning that according to EC (CARE) data [23, 32-33] there were more than 1.36 million accidents in Europe total. In terms of the number of accidents, this placed Poland

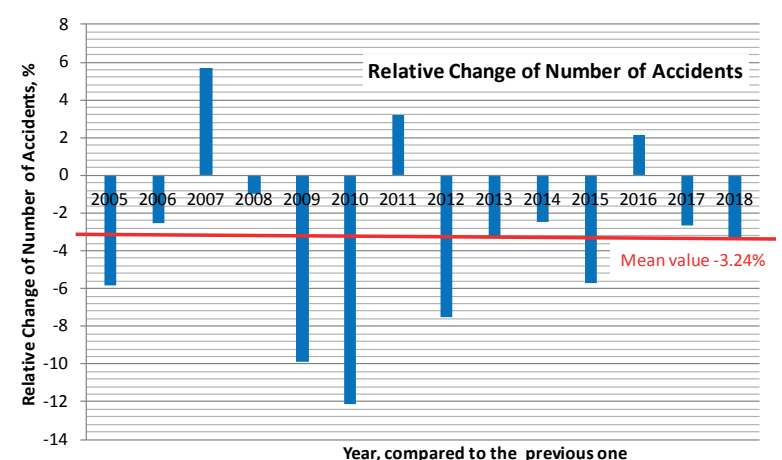

Figure 7 Relative change in the number of accidents

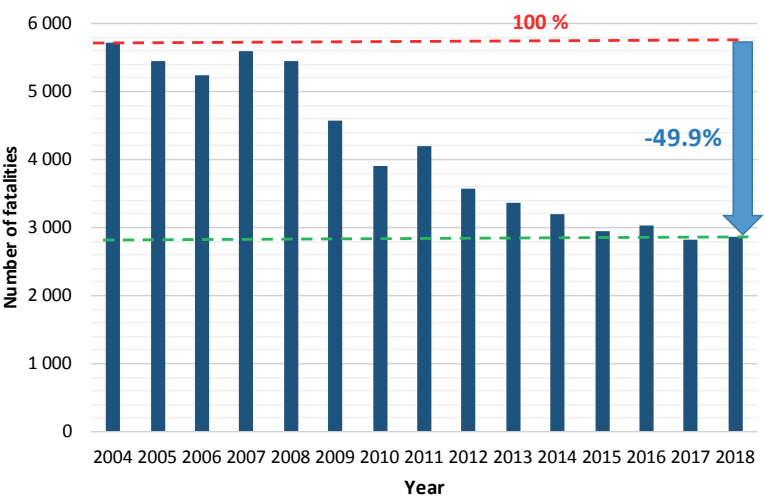

Figure 8 Number of fatalities on Polish roads in 2004-2018

among the top European countries. In this respect Poland was surpassed by such countries as: Germany with 339 thousand accidents, Italy -243 thousand, Great Britain -213 thousand or, the similar in terms of area and population, Spain -94 thousand. It should be noted, however, that the way in which accidents are counted and defined varies from country to country, making it very difficult to compare these data in full. During a meeting of EU transport ministers in Valetta, attention was also drawn to the fact that EU Member States should report traffic accidents using a common definition of "accidents", using comparable and reliable data $[28,34]$.

Since 1997, there has been a clear decrease in the number of accidents in Poland. When the analysis is narrowed down to the period 2004-2018 (see Figure 6) it can be seen that the number of accidents since Poland's accession to the EU has decreased by 38\%. It is worth noting, however, that at the same time in the analyzed period the number of vehicles increased by nearly $80 \%$.

The value of the relative change in the number of accidents is shown in Figure 7, the average value (marked with a red line) in the analyzed years amounted to $-3.24 \%$. This indicates an annual statistical decrease in the number of accidents. The largest decrease, i.e. approx. $10 \%$ and over, was recorded in the years 2009-2010. However, the downward trend was not recorded annually, as in 2007 the highest increase in the number of accidents was recorded, reaching $6 \%$.

In 2004, a total of 47,900 people died in EU countries. In Poland, this value was 5,712. Calculated per million citizens, 
Table 1 Coefficient of determination $R^{2}$ for the accident data in different European countries

\begin{tabular}{|c|c|c|c|}
\hline Country & Coefficient of determination $\mathrm{R}^{2}$ & Country & Coefficient of determination $\mathrm{R}^{2}$ \\
\hline Austria & 0.450 & Italy & 0.912 \\
\hline Belgium & 0.754 & Latvia & 0.893 \\
\hline Bulgaria & 0.733 & Lithuania & 0.969 \\
\hline Croatia & 0.934 & Luxembourg & 0.870 \\
\hline Czech Republic & 0.828 & Malta & 0.043 \\
\hline Cyprus & 0.830 & Netherlands & 0.714 \\
\hline Denmark & 0.827 & Poland & 0.994 \\
\hline Estonia & 0.981 & Portugal & 0.819 \\
\hline France & 0.941 & Romania & 0.006 \\
\hline Finland & 0.754 & Slovakia & 0.667 \\
\hline Germany & 0.922 & Slovenia & 0.919 \\
\hline Greece & 0.928 & Spain & 0.230 \\
\hline Hungary & 0.982 & Sweden & 0.960 \\
\hline \multirow[t]{2}{*}{ Ireland } & 0.249 & UK & 0.960 \\
\hline & & $\mathrm{EU}$ & 0.988 \\
\hline
\end{tabular}

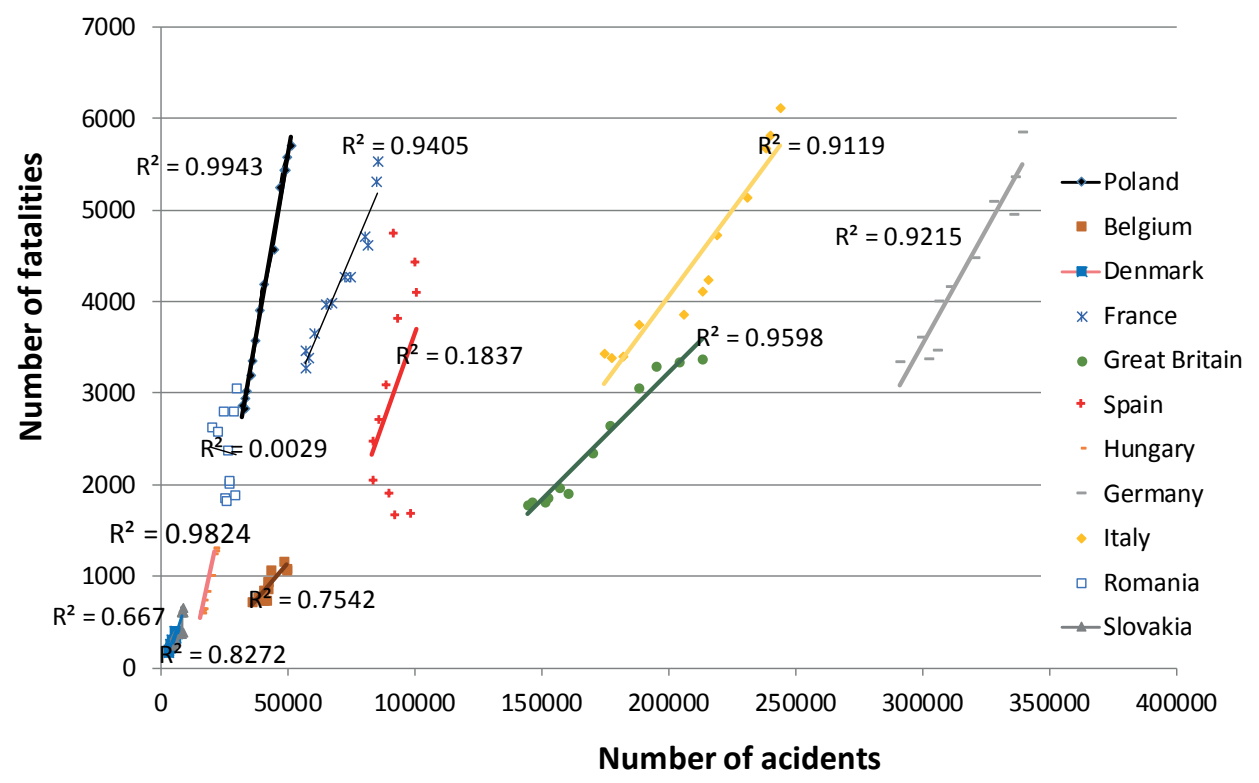

Figure 9 Number of road accidents versus the number of fatalities for several member states of the EU

this means that, in 2004, there were almost 150 fatalities in traffic accidents per million citizens. In the period 2004-2018 the number of fatalities on Polish roads decreased by nearly $50 \%$ (Figure 8).

In 2018, 3,862 fatalities were recorded, which means that statistically 76 people per 1 million citizens died on the roads in Poland. Taking into account the fact that the EU average in 2018 in this respect was 49, Poland ranked fifth in this unfavorable ranking. Poland was ahead of Romania (96), Bulgaria (88), Latvia (78) and Croatia (77) in this respect. United Kingdom (28), Denmark (29), Ireland and Netherlands (31) and Sweden (32) have been identified as the safest countries in this respect [33]. According to incomplete data, in 2018 there were around 25,300 fatalities and 135,000 injured on the EU roads [30].
Analysing the available information presented by CARE $[23,33]$, one wonders whether there is any relationship between the number of road accidents and the number of fatalities. From the data presented in [34] it is clear that the number of accidents in Poland is largely dependent on the number of people killed. If one compares the results provided in Figure 9, it can be seen that the coefficient of determination $\mathrm{R}^{2}$ for Poland is very high, reaching approximately 0.99 . High values are also reported for such countries as Hungary $\left(R^{2}=0.982\right)$, Estonia $\left(R^{2}=0.981\right)$, Lithuania $\left(R^{2}=0.982\right)$ and the UK $\left(R^{2}=0.96\right)$. The values indicate that if the number of road accidents is reduced, the number of fatalities will decrease, too. However, reducing the number of killed to zero in this way is not possible in practice. The mean coefficient of determination obtained 


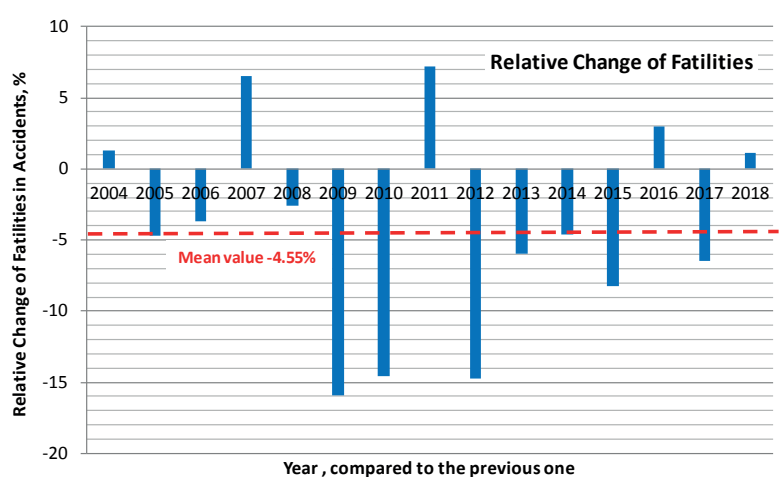

Figure 10 Relative decrease in the number of fatalities

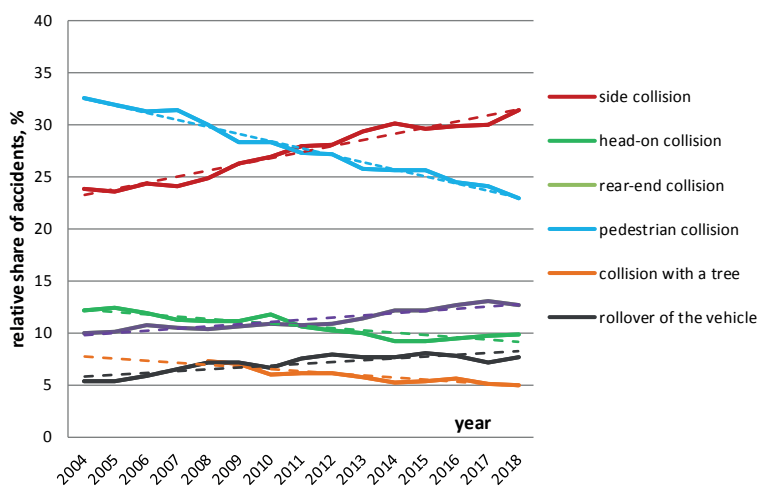

Figure 11 Specificity of traffic accidents in Poland

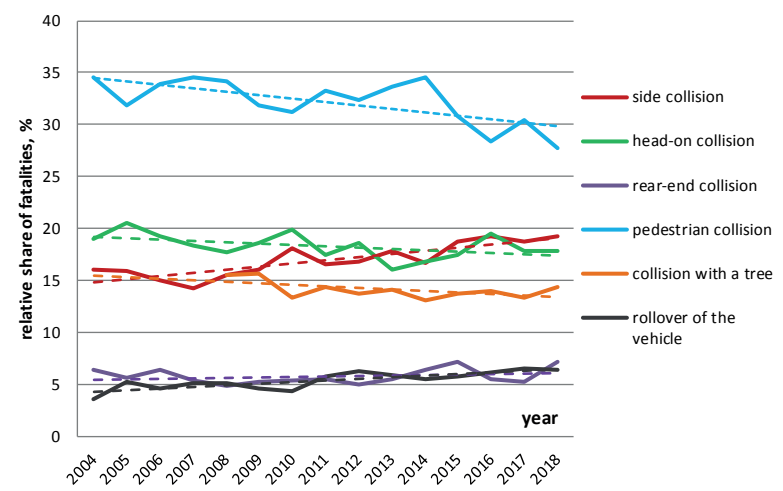

Figure 12 Specificity of fatalities in the main types of traffic accidents in Poland

for the total number of accidents and the total number of fatalities in the EU member states is $R^{2}=0.988$. The lowest values of $R^{2}$ are observed for Romania $\left(R^{2}=0.006\right)$, Malta $\left(R^{2}=0.043\right)$ and Luxembourg $\left(R^{2}=0.087\right)$, which suggests that there is no such relationship for these countries.

Table 1 shows the values of the coefficient of determination $R^{2}$, being the ratio of the number of road accidents to the number of fatalities, obtained for selected EU member states in the analysed period.

Figure 10 presents the results of analysis of the relative annual changes in the number of traffic accident fatalities.

In certain years (especially in 2009, 2010 and 2012) quite a significant reduction of their value -by about 15\%, was recorded. Only in four years of the analyzed period, an increase was recorded, with the highest in 2011 (by

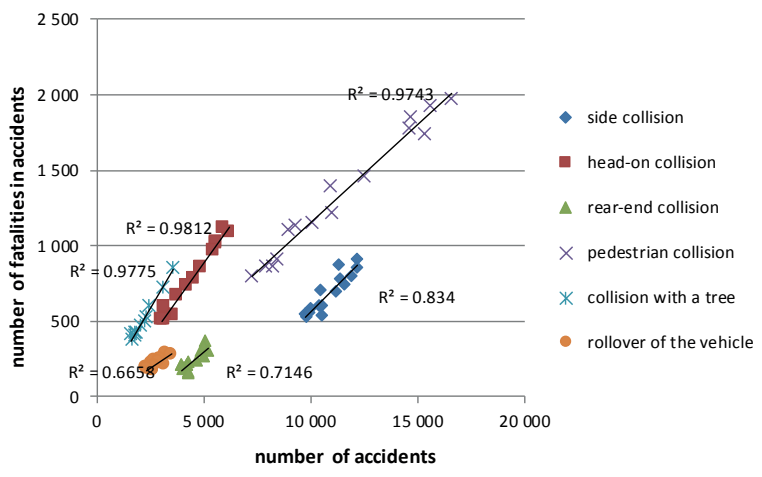

Figure 13 Dependency of number of fatalities on number of accidents

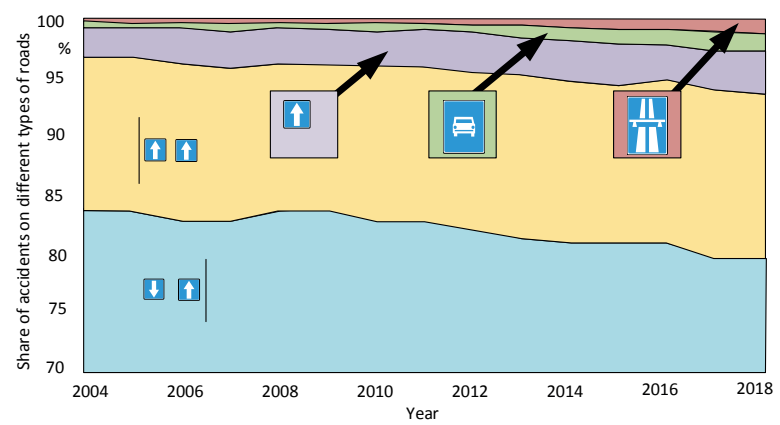

Figure 14 Share of accidents on different types of roads in Poland

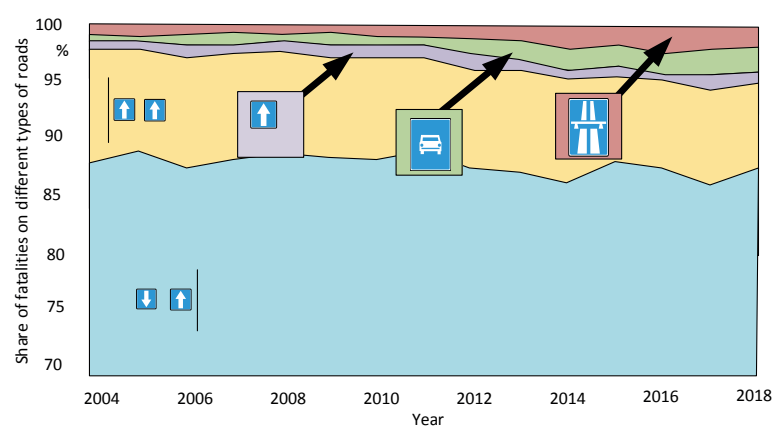

Figure 15 Graphic representation of the shares of fatalities on particular types of roads in Poland

$7 \%)$. The average decrease in the relative number of road fatalities in the analyzed period was $4.55 \%$.

When analyzing the state of the road safety in the period in question, accidents where divided in the main types as presented in Figure 11.

Analyzing the specificity of accidents, it is worth noting that in the years 2004-2019, the share of side collisions caused by e.g. not yielding when appropriate, as well as rear-end collisions and rollovers, significantly increased. It is worth emphasizing that, in the analyzed period, the share of pedestrian collisions significantly decreased from $33 \%$ to about $24 \%$ [18, 35]. Despite the number of accidents involving pedestrians still being high, this decrease can be deemed positive, as almost every accident with participation 
of the so-called unprotected road users results in a fatality or serious injury [25].

Figure 12 presents the share of fatalities in this type of accidents. The largest, although decreasing (over 30\%) share in the number of fatalities are accidents related to pedestrians being run over. This is followed by the head-on collisions (20\%), although it can be seen that the side collisions have been equally dangerous in recent years.

Figure 13 presents the results of the correlation analysis between the number of accidents and the number of fatalities in different types of accidents.

When analyzing the graph in Figure 13, it can be seen that the high value of the coefficient of determination confirms the close dependency between the number of accidents and fatalities. The lowest coefficient of determination occurs in case of rollovers and amounts to $\mathrm{R}^{2}=0.665$. The highest coefficients were recorded for head-on collisions $\left(\mathrm{R}^{2}=0.981\right)$, collisions with trees $\left(\mathrm{R}^{2}=0.977\right)$ or pedestrian collisions $\left(\mathrm{R}^{2}=0.971\right)$, which means that these types of accidents have the greatest impact on the number of fatalities.

Figure 14 presents a summary of accidents occurring on different types of roads. The following types of roads were considered:

a) "A" -two-way, two-lane roads,

b) "B" -one-way, two-lane roads,

c) "C" -one-way, single-lane roads,

d) "E" -expressways,

e) "M"-motorways.

The dominant type of roads (and at the same time the most common in Poland) with regards to number of accidents recorded were type "A" roads. Despite a number of investments, the share of accidents on these roads was over $80 \%$. On type "B" roads the percentage of accidents was approx. $13 \%$, on type "C" roads it was around $3-4 \%$, while on roads type "M" and "E" it was approx. 1.5\% [18].

Since the share of accidents on roads type "C", "E" and "M" is relatively small, the range of values on the ordinate axis in the graph presented in Figure 14 was narrowed down to $70 \%-100 \%$ in order to improve its legibility [18].

Figure 15 presents a summary of the types of roads on which fatal accidents are recorded. The dominant type of roads in this respect were type "A" roads, i.e. two-way, two-lane roads. The share of fatalities on these roads was nearly $86-88 \%$.
Comparing Figures 14 and 15, there are certain clear trends in the analyzed period. The share of accidents on type "A" roads, i.e. two-way, two-lane roads is decreasing (a decrease of about $4 \%$ was recorded), but it did not result in a significant decrease in the share of fatalities on these roads (about $-0.6 \%$ ). A minor increase (by about 1\%) in the number of accidents on other types of roads resulted in a decrease in the share of fatalities on roads type "B" by $2.3 \%$ and the increase on motorways (type "M") and expressways (type "E") by slightly more than $1 \%$.

\section{Conclusions}

In 2004, Poland has joined the European Union. Since then, a visible qualitative change is taking place in many areas in Poland. In the area of transport and road safety, certain changes and regularities could also be observed over the past 15 years. It is easily noticeable that the number of registered cars in Poland in 2018 grew to nearly 30 million with over 22.5 million passenger cars. When analyzing these data in relation to the base year 2004, one can speak of increases of $77.6 \%$ and $88 \%$, respectively. The annual increase of the number of vehicles in certain years was as high as $10 \%$. These vehicles make use of the available road network. The total length of all public roads in Poland increased by about 10\%, in the case of the most significant roads and best in terms of their technical characteristics, the increase was more pronounced. The changes in the linear infrastructure were accompanied by changes in the statistics of traffic incidents. In the analyzed period, the number of accidents dropped by $38 \%$ and the number of fatalities by nearly $50 \%$.

The high values of the coefficient of determination $\mathrm{R}^{2}$ reported for several European countries, including Poland, confirm that one of the ways to reduce the number of fatalities is reducing the number of accidents.

Analyzing the number of accidents and fatalities, a very strong correlation $\left(R^{2}>0.97\right)$ between the number of accidents and the number of fatalities was confirmed, in case of certain types of accidents: head-on collisions, collisions with trees or pedestrians. Analyzing the structure of the road network, a summary was made of the types of roads on which accidents and fatal accidents took place. The most dangerous roads in Poland are two-way, two-lane roads.

\section{References}

[1] JAZDZIK-OSMOLSKA, A. Wycena kosztow wypadkow i kolizji drogowych na sieci drog w Polsce na koniec roku 2015 - z wyodrebnieniem srednich kosztow spoleczno-ekonomicznych wypadkow na transeuropejskiej sieci transportowej, IBDiM / Valuation of the costs of road accidents and collisions on the road network in Poland at the end of 2015 with isolation of the average socio-economic costs of accidents on the trans-European transport network (in Polish) [online]. Warszawa: Wydawca Ministerstwo Infrastruktury i Rozwoju, Sekretariat KRBRD, 2016. Available from: http://www.krbrd.gov.pl/files/file_add/download/393_wycena-kosztow-wypadkow-i-kolizji-drogowych-2015.pdf

[2] WESZCZAK, A. (2018). Ekonomiczne i spoleczne determinanty bezpieczenstwa ruchu drogowego w Polsce. Analizy regionalne / Economic and social determinants of road safety in Poland. Regional analyzes (in Polish). 
$\mathrm{PhD}$ dissertation [online]. Available from: http://dspace.uni.lodz.pl/xmlui/bitstream/handle/11089/25186/BRD. pdf?sequence $=1 \&$ isAllowed $=y$

[3] CABAN, J., DROZDZIEL, P., LISCAK, S. Wybrane aspekty stanu bezpieczenstwa w transporcie drogowym / Selected aspects of the state of safety in road transport (in Polish). Zeszyty Naukowe Instytutu Pojazdow. 2012, 3(89), p. 13-19. ISSN 1642-347X.

[4] CABAN, J., DROZDZIEL, P., MARCZUK, A., KLUSKA, A. Przyczyny powstawania wypadkow drogowych w Polsce / Causes of road accidents in Poland (in Polish). Logistyka. 2015, 5, p. 703-710. ISSN 1231-5478.

[5] GONIEWICZ, M., GONIEWICZ, K. Wypadki drogowe w Polsce - czynniki sprawcze i zapobieganie / Road accidents in Poland - the causative factors and prevention (in Polish). Bezpieczenstwo Pracy: Nauka i Praktyka. 2010, 09, p. 14-17. ISSN 0137-7043.

[6] Hiszpania na pierwszym miejscu. Spain in the first place (in Polish) [online]. Available from: https://inzynieria.com/ wpis-branzy/rankingi/5/53404,w-ktorym-kraju-ue-jest-najdluzsza-siec-autostrad-ranking,pozycja-rankingu-hiszpaniana-pierwszym-miejscu

[7] JASKIEWICZ, M., JURECKI, R., LISCAK, S. STOKLOSA, J. Analysis of the state of road safety in Swietokrzyskie voivodeship. XIV International Technical Systems Degradation Conference: proceedings. 2015, p. 25-28.

[8] JURECKI, R., POLIAK, M. Traffic safety of main roads in Poland. New Trends in Production Engineering [online]. 2018, 1(1), p. 63-72. ISSN 2545-2843. Available from: https://doi.org/10.2478/ntpe-2018-0008

[9] JASKIEWICZ, M., JURECKI, R. The analysis of safety on Polish roads between 2000 and 2010. Transport and Communication. 2013, 1, p. 8-40. ISSN 1339-5130.

[10] BARCIK, J., CZECH, P. Wplyw infrastruktury drogowej na bezpieczenstwo ruchu-czesc I / Condition of rail transport in Poland in recent years - part 1 (in Polish). Zeszyty Naukowe Politechniki Slaskiej. Seria Transport / Scientific Journal of Silesian University of Technology. Series Transport [online]. 2010, 67, p. 13-21. ISSN 0209-3324, eISSN 2450-1549. Available from: http://sjsutst.polsl.pl/archives/2010/vol67/005_ZN67_2010_BarcikCzech.pdf

[11] WINTER, W., ZOLTOWSKI, B. Czynniki techniczne w ryzyku powstawania wypadkow drogowych / Technical factors in the risk of road accidents (in Polish). Zeszyty Naukowe Politechniki Swietokrzyskiej. Mechanika. 2006, 84, p. 339-350. ISSN 0239-4979.

[12] BAK, J., BAK-GAJDA, D. Psychologiczne czynniki bezpieczenstwa ruchu drogowego / Psychological factors of road safety (in Polish). Maintenance and Reliability - Eksploatacja i Niezawodnosc. 2008, 3(39), p. 22-29. ISSN 1507-2711.

[13] MATUSZAK Z., NOWAK, A., ZABINSKA, I., MARTINEZ DE OSES, F. X. Road safety on the example of the city of Bytom. The Archives of Automotive Engineering - Archiwum Motoryzacji [online]. 2019, 83(1), p. 43-57. eISSN 2084-476X. Available from: https://doi.org/10.14669/AM.VOL83.ART3

[14] METELSKI, A. Analysis of selected methodological problems regarding the examination of traffic events at road intersections. The Archives of Automotive Engineering - Archiwum Motoryzacji [online]. 2018, 82(4), p. 75-85. eISSN 2084-476X. Available from: https://doi.org/10.14669/AM.VOL82.ART6

[15] BROZYNA, E. Czynnik ludzki a bezpieczenstwo w ruchu drogowym / The Human factor and road safety (in Polish). Autobusy: Technika, Eksploatacja, Systemy Transportowe. 2017, 7-8, p. 49-52. ISSN 1509-5878. e-ISSN 2450-7725.

[16] KISILOWSKI, J., ZALEWSKI, J. Wybrane problemy analizy przyczyn wypadkow drogowych w Polsce w latach 19952004 / Selected problems of analyzing the causes of road accidents in Poland in 1995-2004. Maintenace and Realibility - Eksploatacja i Niezawodnosc. 2008, 1, p. 37-43. ISSN 1507-2711.

[17] RACZYNSKA-BULAWA, E. Bezpieczenstwo w ruchu drogowym w Europie: zalozenia polityki UE i ocena podejmowanych dzialan z perspektywy danych statystycznych / Traffic Safety in Europe - the policy of UE and evaluation activities undertaken from the perspective of statistical data. Autobusy: Technika, Eksploatacja, Systemy Transportowe. 2016, 10, p. 8-14. ISSN 1509-5878. e-ISSN 2450-7725.

[18] Annual reports of Police HQ Accidents 2004-20018 (in Polish) [online]. Available from: http://statystyka.policja.pl/st/ ruch-drogowy/76562,Wypadki-drogowe-raporty-roczne.html

[19] Ludnosc. Stan i struktura oraz ruch naturalny w przekroju terytorialnym w 2018 r. Stan w dniu 31 XII / Population. Condition and structure, as well as natural movement in territorial division in 2018. As of 31 XII (in Polish) [online]. Available from: http://stat.gov.pl/obszary-tematyczne/ludnosc/ludnosc/ludnosc-stan-i-struktura-oraz-ruch-naturalny-wprzekroju-terytorialnym-w-2018-r-stan-w-dniu-31-xii,6,25.html

[20] Drogi publiczne/Public roads [online]. Available from: http://drogipubliczne.eu/drogi-publiczne-w-liczbach

[21] National roads in Poland. (in Polish) [online]. Available from: https://www.gddkia.gov.pl/pl/927/drogi-krajowe

[22] Motorways in Poland (in Polish) [online]. Available from: https://www.gddkia.gov.pl/pl/926/autostrady

[23] CARE (EU Road Accidents Database) [online] Available from: https://ec.europa.eu/transport/road_safety/specialist/ statistics_en\#

[24] Program budowy drog krajowych / National road construction program (in Polish) [online]. Available from: https://www.gddkia.gov.pl/pl/4059/Program-Budowy-Drog-Krajowych-sprawdz-stan-zaawansowania 
[25] JURECKI, R., JASKIEWICZ, M., WIECKOWSKI, D. Bezpieczenstwo niechronionych uczestnikow ruchu drogowego w Polsce / Safety of unprotected road users in Poland (in Polish). Autobusy. Technika, Eksploatacja, Systemy Transportowe. 2016, 11, p. 75-81. ISSN 1509-5878. e-ISSN 2450-7725.

[26] K.R.B.R. Narodowy Program Bezpieczenstwa Ruchu Drogowego 2013-2020. Material na posiedzenie plenarne KRBRD 20.06.2013 / National Road Safety Program 2013-2020. Material for the KRBRD plenary session on 20/06/2013 (in Polish) [online]. Available from: http://www.krbrd.gov.pl/files/file/NP-BRD-2020_przyjety_przez_KRBRD.pdf

[27] PLACHECKA, M. Efekty dzialan na rzecz poprawy bezpieczenstwa w transporcie publicznym w Polsce / Effects of actions to improve safety in public transport in Poland (in Polish). Autobusy: Technika, Eksploatacja, Systemy Transportowe. 2016, 10, p. 20-23. ISSN 1509-5878. e-ISSN 2450-7725.

[28] Declaration Transport ministers of the Member States of the European Union. Meeting in Valletta on 29 March 2017 [online. Available from: http://data.consilium.europa.eu/doc/document/ST-6273-2017-INIT/en/pdf

[29] Road safety citizen [online]. Available from: https://ec.europa.eu/ transport/road_safety/sites/roadsafety/files/pdf/ road_safety_citizen/road_safety_citizen_100924_en.pdf

[30] Statystyki umieralnosci na drogach w UE / Road mortality statistics in the EU (in Polish) [online]. Available from: http://www.europarl.europa.eu/news/pl/headlines/society/20190410STO36615/statystyki-smiertelnosci-na-drogach-wue-infografika

[31] WILK, T., GAWRON A. Analiza stanu bezpieczenstwa ruchu drogowego dla obszaru miasta / Analysis of road traffic safety for the city area (in Polish). Logistyka. 2014, 3, p. 1698-1706. ISSN 1231-5478.

[33] EU Road Safety Policy Framework 2021-2030 - Next steps towards "Vision Zero" [online]. Available from: https://ec.europa.eu/transport/road_safety/sites/roadsafety/files/move-2019-01178-01-00-en-tra-00_3.pdf

[34] 2018 road safety statistics [online]. Available from: https://europa.eu/rapid/press-release_MEMO-19-1990_en.htm

[34] Mobility and transport, road safety [online]. Available from: https://ec.europa.eu/transport/road_safety/specialist/ statistics_en\#

[35] JURECKI R. Wybrane zagadnienia bezpieczenstwa pieszych na drogach w Polsce / Selected issues of pedestrian safety on roads in Poland (in Polish). Technika Transportu Szynowego. 2015, 12, p. 746-749. ISSN 1232-3829, e-ISSN 2543-5728. 